\title{
Absence of Crimean-Congo haemorrhagic fever virus in the tick Hyalomma aegyptium parasitizing the spur-thighed tortoise (Testudo graeca) in Tunisia
}

\author{
Wasfi Fares ${ }^{1, a}$, Khalil Dachraoui ${ }^{1, a}$, Chawki Najjar ${ }^{1,2}$, Hend Younsi $^{3}$, Stephen Findlay-Wilson ${ }^{4}$, Marie Petretto ${ }^{2}$, \\ Stuart Dowall ${ }^{4}$, Roger Hewson ${ }^{4}$, and Elyes Zhioua ${ }^{1, *}$ \\ ${ }^{1}$ Institut Pasteur de Tunis, Laboratory of Vector Ecology, 13 Place Pasteur, 1002 Tunis, Tunisia \\ ${ }^{2}$ Marwell Wildlife Colden Common, Thompsons Lane, Winchester, SO21 1JH Hampshire, UK \\ ${ }^{3}$ Institut Supérieur des Sciences Biologiques Appliquées de Tunis, Université Tunis El Manar, 9 Avenue Zouhaïer Essafi, \\ 1009 Tunis, Tunisia \\ ${ }^{4}$ Public Health England, Manor Farm Road, Porton Down, Salisbury, SP4 0JG Wiltshire, UK
}

Received 14 April 2019, Accepted 28 May 2019, Published online 14 June 2019

\begin{abstract}
Free-ranging spur-thighed tortoises Testudo graeca, captured in different habitat types of Northern Tunisia from March to April 2017, were examined for tick infestation: 134/147 (91\%) were infested. The overall infestation intensity and abundance was 8.5 and 7.8, respectively. From these tortoises, 1174 ticks were collected, of which $10 \%(n=120)$ taken from 18 randomly-selected tortoises were identified at the species level; the remaining ticks were examined for the presence of Crimean-Congo haemorrhagic fever virus (CCHFv) by real time RT-PCR. Only adult Hyalomma aegyptium were found, suggesting a high degree of host specificity to tortoises. No CCHFv was detected in ticks. Considering the absence of CCHFv in Hyalomma aegyptium infesting its main host, the spur-thighed tortoise, this tick species is unlikely to play a major role in the epidemiology of CCHF. Therefore, more studies are needed to investigate the circulation of this arbovirus between livestock and other tick species from North Africa.
\end{abstract}

Key words: Crimean-Congo haemorrhagic fever virus, Hyalomma aegyptium, Testudo graeca, North Africa.

Résumé - Absence du virus de la fièvre hémorragique de Crimée-Congo chez la tique Hyalomma aegyptium parasitant la tortue grecque (Testudo graeca) en Tunisie. Des tortues grecques, Testudo graeca, capturées dans différents types d'habitats du nord de la Tunisie de mars à avril 2017 ont été examinées pour la présence de tiques : 134/147 (91\%) étaient infestées. L'intensité d'infestation et l'abondance globale étaient respectivement de 8,5 et 7,8. Des tiques $(n=1174)$ ont été collectées de ces tortues, dont $10 \%(\mathrm{n}=120)$ prélevées sur 18 tortues sélectionnées au hasard ont été identifiées au niveau de l'espèce, et les tiques restantes ont été examinées pour la présence du virus de la fièvre hémorragique de Crimée-Congo (vFHCC) par RT-PCR. Seuls des Hyalomma aegyptium adultes ont été trouvés, ce qui suggère un degré élevé de spécificité de cette espèce de tique pour les tortues Aucun vFHCC n'a été détecté dans les tiques. Compte tenu de l'absence du vFHCC chez Hyalomma aegyptium collecté de tortues (Testudo graeca), cette espèce de tique ne joue probablement pas un rôle important dans l'épidémiologie de la FHCC. Par conséquent, d'autres études sont nécessaires pour investiguer la circulation de cet arbovirus entre le bétail et d'autres espèces de tiques d'Afrique du Nord.

\section{Introduction}

Crimean-Congo haemorrhagic fever (CCHF), a tick-borne disease caused by the Crimean-Congo haemorrhagic fever virus (CCHFv) (family Bunyaviridae, genus Nairovirus) is characterized by fever and hemorrhage with case fatality rates of $9-50 \%$ $[10,43]$. CCHFv is transmitted in nature mainly by hard ticks of the genus Hyalomma [13, 36]. Ticks are considered a vector and also a reservoir because they are able to maintain the virus during its life cycle by transstadial transmission and can be passed onto offspring by transovarial transmission [47]. CCHFv is maintained in nature through a transmission cycle involving ticks and vertebrate hosts, mainly domestic animals such as cattle, and sheep [21]. CCHF has been reported in Africa [29, 44], Asia [28], the Middle East [34], and Eastern Europe $[17,46]$. In the Western Mediterranean Basin, the first case of CCHF was reported from Spain in 2016 [16]. To date, only one published study performed in Tunisia reported a

\footnotetext{
*Corresponding author: elyes. zhioua@gmail. com
}

${ }^{\mathrm{a}}$ Authors with the same contribution to this paper. 
seroprevalence of 5\% among slaughter workers considered to be an at-risk human population, suggesting silent circulation of CCHFv [15]. Thus, epidemiological surveys of ticks, humans, and domestic and wild animals for CCHFv in Tunisia are of major importance.

Recently, CCHFv has been detected in Hyalomma aegyptium collected from spur-thighed tortoises (Testudo graeca) captured in Algeria [23] and in Syria [39]. Thus, it is of particular epidemiological interest to study the impact of the high infestation intensity in $T$. graeca by $H$. aegyptium on the potential transmission of zoonotic pathogens such as $\mathrm{CCHFv}$ in the Mediterranean Basin. Hyalomma aegyptium has a three-host life cycle where larvae and nymphs infest a wide range of hosts including lizards, birds, small mammals [2, 25], and accidentally cattle [4], and humans [8, 42]. By contrast, adult $H$. aegyptium is host-specific to tortoises, particularly $T$. graeca $[2,22$, $35,37-40]$. The geographical distribution of $H$. aegyptium covers the Mediterranean basin, the Balkans, and the Middle East $[2,25]$; they are exotic elsewhere [7]. In addition to CCHFv, H. aegyptium is known to be a vector of Hemolivia mauritanica [38]. This tick species has been found to be infected with other human and animal pathogens such as Anaplasma phagocytophilum, Ehrlichia canis, Coxiella burnetii [31], and Rickettsia aeschlimannii [5].

Even though the spur-thighed tortoise is a protected species, it is commonly used illegally as a garden pet in Tunisia, in addition to being subject to thriving illegal trade between North Africa and Europe $[6,18]$. The potential for T. graeca to transmit zoonotic pathogens is greater when $H$. aegyptium is infesting humans [8]. To increase our understanding of the epidemiology of $\mathrm{CCHF}$, we assessed $\mathrm{CCHFv}$ infection in $H$. aegyptium collected from field-captured T. graeca in Tunisia.

\section{Materials and methods Ethics}

The spur-thighed tortoise (T. graeca) is a protected species in Tunisia and subsequently any study involving this tortoise species must obtain prior approval from the General Directorate of Forest at the Tunisian Department of Agriculture. Our study was performed following approval from this authority (authorization no. 645, following an application submitted by Marwell Wildlife No. 1441 of 13 March 2017). Capture and handling of tortoises were performed by a trained veterinarian (C. Najjar) to minimize stress and pain.

\section{Tortoise search and tick collection}

Wild tortoises from different sites, located in humid and subhumid bio-geographical areas of Northern Tunisia (Fig. 1), were sampled on foot transects conducted in their natural habitats between March and May 2017. Captured tortoises were identified on site, using identification keys [11, 19]: the endemic T. graeca has distinctive morphological traits that allow quick taxonomical identification. Tortoise age was also estimated by counting the scute rings (annuli) [9]. Each tortoise was examined thoroughly for the presence of ticks and released at the point of capture. The number of ticks and their attachment sites were reg- istered for each tortoise. Collected ticks were placed in snap-cup vials and stored at $-80^{\circ} \mathrm{C}$ until use. Tick species identification was performed on the whole tick load of a random sample of the captured tortoises, using the identification keys of Hoogstraal [20]; the remaining collected ticks were kept at $-80^{\circ} \mathrm{C}$ to be examined later for the presence CCHFv. The number of tortoises screened was determined using Research Advisors' sample size table corrected with the assumption that the proportion of $H$. aegyptium will be substantially different from $50 \%$ of the ticks collected, and allowing a subsequent reliable survey of pathogen infection incidence within the remaining ecto-parasites (Confidence Level $=95 \%$; Margin of Error $=1 \%$ ). Consequently, the ticks of $13.4 \%(n=18)$ of the infested tortoises were identified, representing about $10 \%(n=120)$ of the total collected.

\section{Molecular analysis}

Ticks were examined for the presence of CCHFv by realtime reverse transcription (RT)-PCR [3]. Collected ticks were pooled according to the trapping location with a maximum of 10 individuals per pool for the non-engorged ticks and two per pool for engorged ticks, resulting in a total of 46 pools. The pools of ticks were transferred to PreCellys tubes containing silica beads and $0.5 \mathrm{~mL}$ of MEM and homogenized three times at $5600 \mathrm{rpm}$ for $30 \mathrm{~s}$, and finally centrifuged at $6000 \mathrm{rpm}$ for $15 \mathrm{~min}$. The total RNA was extracted with a Qiagen viral RNA mini kit from tick supernatant. The presence of CCHFv RNA was determined by qualitative real time RT-PCR performed on the $\mathrm{S}$ segment using the combination of the primer pairs CCHFV.S122F $\left(5^{\prime \prime} \mathrm{CCT}\right.$ TTT TGA ACT CTT CAA ACC $\left.3^{\prime}\right) / C C H F V . S 1 R ~\left(5^{\prime}\right.$ TCT CAA AGA AAC ACG TGC C $3^{\prime}$ ) and the CCHFv probe (5'FAM $3^{\prime}$ ACT CAA GGK AAC ACT GTG GGC GTA AG-BHQ1), as published previously [3]. The real time RT-PCR was performed using the SuperScript III Platinum one step Quantitative RT-PCR system (Invitrogen Life Technologies), according to the manufacturer's instructions. One high and one low CCHFv viral RNA were used as positive controls. A volume of $5 \mu \mathrm{L}$ of total extracted RNA was used for CCHFv genome detection.

\section{Results and discussion}

A total of 147 tortoises (63 males, 72 females, 12 juveniles) were captured and identified as T. graeca. A total of 1174 ticks were collected. $10 \%$ of the collected ticks $(n=120)$ taken from 18 randomly selected tortoises were used for tick identifications: all were identified as adult $H$. aegyptium; there were 88 males and 32 females. Of a total of 147 examined tortoises, 134 were infested with at least one tick, yielding an infestation prevalence of $91.16 \%$. The overall infestation intensity and abundance was 8.5 and 7.8 , respectively. We observed higher overall infestation intensities compared to those reported from Algeria (1.7-9.4 [41]), Jordan (0.2-5.9 [32]), the Balkans (1.3 [37]), Russia (5.2 [33]), Italy (3.9 on tortoises imported from North Africa [6]), Tunisia (4.3 on tortoises seized by customs [18]), and Morocco (6.67 [35]). Our results provide strong evidence of the high dependence of adult $H$. aegyptium on its host $T$. graeca. 


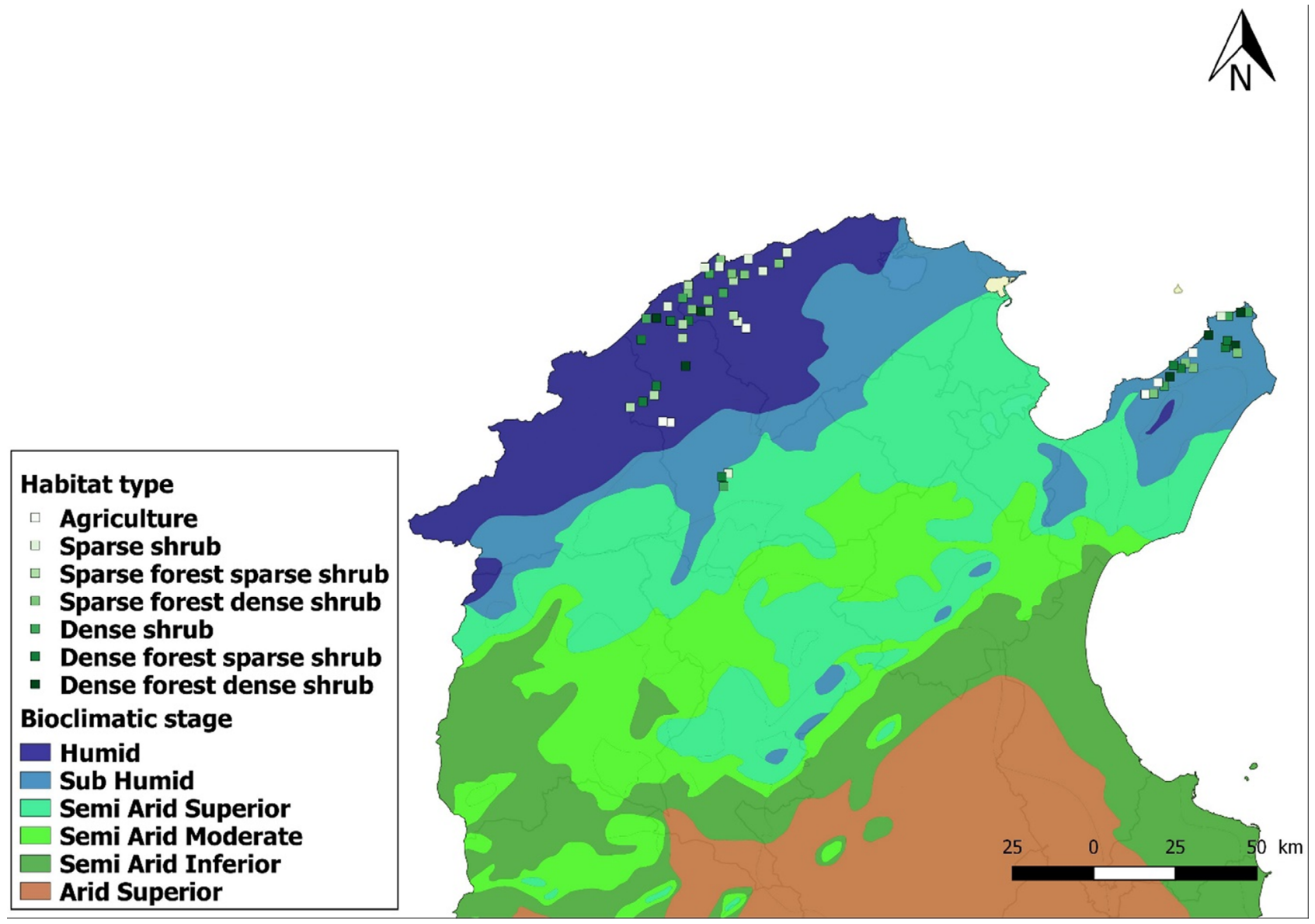

Figure 1. Map of the Tunisian bioclimatic stages and habitat types searched for free-ranging spur-thighed tortoises (squares).

In the present study, no CCHFv was detected in H. aegyptium. In Tunisia, we previously reported the absence of CCHFv in Hyalomma dromedarii and Hyalomma scupense [15]. It is of key epidemiological importance to point out that reported rates of the virus infection in ticks from endemic areas varied from 0 to more than $50 \%$. In Iran, the infection prevalence of field-collected Hyalomma sp. from Yazd province was 5.7\% [45]. In Turkey, from a total of 250 Hyalomma sp. collected from humans with tick bites in an endemic focus of $\mathrm{CCHF}$ ( 25 pools with 10 ticks in each pool) and tested for CCHFv, seven pools were positive, yielding an infection rate of $28 \%$ [8]. In Spain, among 117 Hyalomma lusitanicum specimens collected from red deer, two pools were positive for CCHFv, yielding a minimum infection rate of $1.7 \%$ [13]. Following an outbreak of CCHF in Gujarat, India in 2011, an entomological investigation showed that the infection rate of Hyalomma anatolicum anatolicum with $\mathrm{CCHFv}$ was $1.4 \%$ [28]. From Kosovo, significantly different virus infection rates varying from 0 [14] to $15 \%$ [36] were reported.

While recent reports have demonstrated CCHFv detection in $H$. aegyptium removed from $T$. graeca captured in Algeria [23] and in Syria [39], in our study, real time RT-PCR analysis failed to detect the presence of CCHFv RNA, indicating that adult $H$. aegyptium were not carrying CCHFv. Based on the large number of tick and tortoise samples tested ( $>1000$ ticks and $>150$ tortoises), our negative results strongly suggest the absence of CCHFv in $H$. aegyptium. Therefore, our findings are in contradiction with those from previous studies [23, 39]. Similar results were reported by another study performed in endemic foci for CCHF in Turkey, showing the absence of $\mathrm{CCHFv}$ in $H$. aegyptium collected from tortoises (T. graeca) [24]. Immature ticks collected from $T$. graeca captured in an endemic focus in Bulgaria were also negative for $\mathrm{CCHFv}$ [26]. Several species of Hyalomma collected from endemic foci located in Northern Turkey including $H$. anatolicum, $H$. detritum, and $H$. marginatum were infected with $\mathrm{CCHFv}$, but not $H$. aegyptium collected from $T$. graeca [1]. Taking into account that the life cycle of $H$. aegyptium is not related to livestock but mainly to tortoises, this tick species is unlikely to play a major role in the epidemiology of CCHF.

In conclusion, the extension of CCHF to the Western Mediterranean Basin represents a serious public health threat. This extension is probably related to livestock trade and the spread of infected ticks by migratory birds [30]. Thus, prevention and control of CCHFv are needed to curb the extension of $\mathrm{CCHF}$. Hyalomma marginatum is considered the main vector of CCHFv in the Western Palearctic region [12], and is located mainly in Northwestern Tunisia [27], an area that was not investigated during the study period. Therefore, screening of this tick species and its domestic animal hosts should continue in an effort to identify and confirm the presence of $\mathrm{CCHFv}$ circulating in Tunisia. 


\section{Conflict of interest}

None.

\section{Financial support}

This work was supported by a grant from the US Civilian Research Fund and Development Foundation (CRDF) OISE-16-62883-1 to EZ and SD, the UK Biological Engagement Program (UKBEP), and in part by the British Charity Marwell Wildlife.

\section{References}

1. Albayrak H, Ozan E, Kurt M. 2010. Molecular detection of Crimean-Congo haemorrhagic fever virus (CCHFV) but not West Nile virus (WNV) in hard ticks from provinces in Northern Turkey. Zoonoses and Public Health, 57, e156-e160.

2. Apanaskevich D. 2004. Host-parasite relationships of the genus Hyalomma Koch, 1844 (Acari, Ixodidae) and their connection with microevolutionary process. Parassitologia, 38, 515-523.

3. Atkinson B, Chamberlin J, Logue $\mathrm{CH}$, Cook N, Bruce C, Dowall SD, Hewson R. 2012. Development of a real time RT-PCR assay for the detection of Crimean-Congo hemorrhagic fever virus. Vector-Borne and Zoonotic Diseases, 12, 786-793.

4. Aydn L. 2000. Distribution and species of ticks on ruminants in the southern Marmara Region. Turkish Journal of Parasitology, 24, 194-200.

5. Bitam I, Kernif T, Harrat Z, Parola P, Raoult D. 2009. First detection of Rickettsia aeschlimannii in Hyalomma aegyptium from Algeria. Clinical Microbiology Infection, 15, 253-254.

6. Brianti E, Dantas-Torres F, Giannetto S, Risitano A, Brucato G, Gaglio G, Otranto D. 2010. Risk for the introduction of exotic ticks and pathogens into Italy through the illegal importation of tortoises, Testudo graeca. Medical and Veterinary Entomology, 24, 336-339.

7. Burridge M, Simmons L. 2003. Exotic ticks introduced into the United States on imported reptiles from 1962 to 2001 and their potential roles in international dissemination of diseases. Veterinary Parasitology, 113, 289-320.

8. Bursali A, Tekin S, Orhan M, Adem Keskin A, Muhlis Ozkan M. 2010. Ixodid ticks (Acari: Ixodidae) infesting humans in Tokat Province of Turkey: species diversity and seasonal activity. Journal of Vector Ecology, 35, 180-186.

9. Castanet J, Cheylan M. 1979. Les marques de croissance des os et des écailles comme indicateur de l'âge chez Testudo hermanni et Testudo graeca (Reptilia, Chelonia, Testudinidae). Canadian Journal of Zoology, 57, 1649-1665.

10. Ergonul O. 2006. Crimean-Congo hemorrhagic fever. Lancet Infectious Diseases, 6, 203-214.

11. Ernst CH, Barbour RW. 1989. Turtles of the world. Washington, DC: Smithsonian Institution Press. p. 313.

12. Estrada-Pena A, Jameson L, Medlock J, Vatansever Z, Tishkova F. 2012. Unravelling the ecological complexities of tick-associated Crimean-Congo hemorrhagic fever virus transmission: A gap analysis for the Western Palearctic. Vector-Borne and Zoonotic Disease, 12, 743-752.

13. Estrada-Pena A, Palomar AM, Santibanez P, Sanchez N, Habela MA, Portillo A, Romero L, Oteo JA. 2012. Crimean-Congo hemorrhagic fever virus in ticks, Southwestern Europe, 2010. Emerging Infectious Diseases, 18, 179-180.
14. Fajs L, Humolli I, Saksida A, Knap N, Jelovsek M, Korva M, Dedushaj I, Avsic-Zupanc T. 2012. Prevalence of CrimeanCongo hemorrhagic fever virus in healthy population, livestock and ticks in Kosovo. PLoS One, 9, e110982.

15. Fares W, Dowall S, Ghabbari T, Bosworth A, Chakroun M, Varghese A, Tiouiri H, Ben Jemaa M, Znazen A, Hewson R, Zhioua E, Letaief A. 2016. Sero-epidemiological survey of Crimean-Congo hemorrhagic fever virus in Tunisia. Parasite, 23, 10.

16. Garcia Rada A. 2016. First outbreak of Crimean-Congo hemorrhagic fever in Western Europe kills one man in Spain. BMJ, 354, i4891.

17. Gergova I, Kamarinchev B. 2013. Comparison of the prevalence of Crimean-Congo hemorrhagic fever virus in endemic and non endemic Bulgarian locations. Journal of Vector-Borne Diseases, 50, 265-270.

18. Gharbi M, Rjeibi MR, Rouatbi M, Mabrouk M, Mhadhbi M, Amairia S, Amdouni Y, Boussaadoun MA. 2015. Infestation of the spur-thighed tortoise (Testudo graeca) by Hyalomma aegyptium in Tunisia. Ticks and Tick-Borne Diseases, 6, 352-355.

19. Highfield A. 1990. Tortoises of North Africa; taxonomy, nomenclature, phylogeny and evolution with notes on field studies in Tunisia. Journal of Herpetology, 1, 1-56.

20. Hoogstraal H. 1956. African Ixodoidea. VoI. I. Ticks of the Sudan (with special reference to Equatoria Province and with preliminary reviews of the genera Boophilus, Margaropus, and Hyalomma). DC, USA: US Govt. Printing Office. p. 1101.

21. Hoogstraal H. 1979. The epidemiology of tick-borne CrimeanCongo hemorrhagic fever in Asia, Europe, and Africa. Journal of Medical Entomology, 15, 307-417.

22. Hoogstraal H, Kaiser MN. 1960. Some host relationships of the tortoise tick, Hyalomma (Hyalommasta) aegyptium (L.) (Ixodoidea, Ixodidae) in Turkey. Annals of the Entomological Society of America, 53, 457-458.

23. Kautman M, Tiar G, Papa A, Široký P. 2016. AP92-like Crimean-Congo hemorrhagic fever virus in Hyalomma aegyptium ticks, Algeria. Emering Infectious Diseases, 22, 354.

24. Kireçci E, Özer A, Balkaya I, Taniş H, Deveci S. 2013. Identification of ticks on tortoises (Testudo graeca) and investigation of some pathogens in these ticks in Kahramanmaraş, Turkey. KSU Journal of Natural Sciences, 16, 42-46.

25. Kolonin GV. 2004. Reptiles as hosts of ticks. Russian Journal of herpetology, 11, 177-180.

26. Levi V. 1973. Distribution and seasonal activity in the preimago phases of the ixodid ticks in a focus of hemorrhagic fever (Crimean type). Prague: Proceeding of the third International Congress of Acarology. p. 609.

27. M'ghirbi Y, Yaïch H, Ghorbe A, Bouattour A. 2012. Anaplasma phagocytophilum in horses and ticks in Tunisia. Parasites \& Vectors, 5, 180.

28. Mourya DT, Yadav PD, Shete AM, Gurav JK, Raut CG, Jadi RS, Pawar SD, Nichol ST, Mishra AC. 2012. Detection, isolation and confirmation of Crimean-Congo hemorrhagic fever in human, ticks, and animals in Ahmadabad, India, 2010-2011. PLoS Neglected Tropical Diseases, 6, e1653.

29. Nabeth P, Cheick DO, Lo B, Faye O, Vall IOM, Niang M, Wague B, Dip D, Diallo M, Diallo B, Diop OM, Simon F. 2004. Crimean-Congo hemorrhagic fever, Mauritania. Emerging Infectious Diseases, 10, 2143-2149.

30. Palomar AM, Portillo A, Santibanez P, Mazuelas D, Arizaga J, Crespo A, Gutierrez O, Cuadrado JF, Oteo JA. 2013. Crimean-Congo hemorrhagic fever virus in ticks from migratory birds, Morocco. Emerging Infectious Diseases, 19, 260-263. 
31. Paştiu AI, Matei IA, Mihalca AD, D'Amico G, Dumitrache MO, Kalmár Z, Sándor AD, Lefkaditis M, Gherman CM, Cozma V. 2012. Zoonotic pathogens associated with Hyalomma aegyptium in endangered tortoises: evidence for host-switching behaviour in ticks? Parasites \& Vectors, 5, 301.

32. Petney TN, Al-Yaman F. 1985. Attachment sites of the tortoise tick Hyalomma aegyptium in relation to tick density and physical condition of the host. Journal of Parasitology, 71, 287-289.

33. Robbins RG, Karesh WB, Calle PP, Leontyeva OA, Pereshkolnik SL, Rosenberg S. 1998. First records of Hyalomma aegyptium (Acari: Ixodida: Ixodidae) from the Russian spur-thighed tortoise, Testudo graeca nikolskii, with an analysis of tick population dynamics. Journal of Parasitology, 84, 1303-1305.

34. Rodriguez LL, Maupin GO, Ksiazek TG, Rollin PE, Khan AS, Scharz TF, Lofts RS, Smith JF, Noor AM, Peters CJ, Nichol ST. 1997. Molecular investigation of a multisource outbreak of Crimean-Congo hemorrhagic fever in the United Arab Emirates. American Journal of Tropical Medicine and Hygiene, 57, 512-528.

35. Segura A, Rodríguez O, Ruiz-Fons F, Acevedo O. 2019. Tick parasitism in the Mediterranean spur-thighed tortoises in the Maamora forest, Morocco. Ticks and Tick-Borne Diseases, 10, 286-289.

36. Sherifi K, Cadar D, Muji S, Robaj A, Ahmeti S, Jakupi X, Emmerich P, Krüger A. 2014. Crimean-Congo hemorrhagic fever virus clades V and VI (Europe 1 and 2) in ticks in Kosovo, 2012. PLoS One, 9, e3168.

37. Široký P, Petrželková KJ, Kamler M, Mihalca AD, Modrý D. 2006. Hyalomma aegyptium as dominant tick in tortoises of the genus Testudo in Balkan countries, with notes on its host preferences. Experimental and Applied Acarology, 40, 279-290.

38. Široký P, Mikulíček P, Jandzík D, Kami H, Mihalca AD, Rouag R, Kamler M, Schneider C, Záruba M, Modrý D. 2009. Co-distribution pattern of a haemogregarine Hemolivia mauritanica (Apicomplexa: Haemogregarinidae) and its vector
Hyalomma aegyptium (Metastigmata: Ixodidae). Journal of Parasitology, 95, 728-733.

39. Široký P, Bělohlávek T, Papoušek I, Jandzik D, Mikulíček P, Kubelová M, Zdražilová-Dubská L. 2014. Hidden threat of tortoise ticks: high prevalence of Crimean-Congo haemorrhagic fever virus in ticks Hyalomma aegyptium in the Middle East. Parasites \& Vectors, 7, 101.

40. Tavassoli E, Rahimi-Asiabi N, Tavassoli M. 2007. Hyalomma aegyptium on spur-thighed tortoise (Testudo graeca) in Urmia Region West Azerbaijan, Iran. Iranian Journal of Parasitology, 2, 40-47.

41. Tiar G, Tiar-Saadi M, Benyacoub S, Rouag R, Široký P. 2016. The dependence of Hyalomma aegyptium on its tortoise host Testudo graeca in Algeria. Medical and Veterinary Entomology, 30, 351-359.

42. Vatansever Z, Gargili A, Aysul N, Sengoz G, Estrada-Peña A. 2008. Ticks biting humans in the urban area of Istanbul. Parasitology Research, 102, 551-553.

43. Whitehouse CA. 2004. Crimean-Congo hemorrhagic fever. Antiviral Research, 64, 145-160.

44. Wilson ML, Gonzalez JP, LeGuenno B, Cornet JP, Guillar M, Calvo MA, Digoutte JP, Camicas JL. 1999. Epidemiology of Crimean-congo hemorrhagic fever in Senegal: temporal and spatial patterns. Archives of Virology, Suppl. 1, 323-340.

45. Yaser SA, Sadegh C, Zakkey T, Hassan V, Maryam M, Ali OM, Mojtaba GS. 2011. Crimean-Congo hemorrhagic fever: a molecular survey on hard ticks (Ixodidae) in Yazd province, Iran. Asian Pacific Journal of Tropical Medicine, 4, 61-63.

46. Yilmaz GR, Buzgan T, Irmak H, Safran A, Uzum R, Cevik MA, Torunoglu MZ. 2009. The epidemiology of Crimean-Congo hemorrhagic fever in Turkey, 2002-2007. International Journal of Infectious Diseases, 13, 380-386.

47. Zeller HG, Cornet JP, Camicas JL. 1994. Experimental Transmission of Crimean-Congo hemorrhagic fever virus by West African wild ground-feeding birds to Hyalomma marginatum rupifes ticks. American Journal of Tropical Medicine and Hygiene, 50, 676-681.

Cite this article as: Fares W, Dachraoui K, Najjar C, Younsi H, Findlay-Wilson S, Petretto M, Dowall S, Hewson R \& Zhioua E. 2019. Absence of Crimean-Congo haemorrhagic fever virus in the tick Hyalomma aegyptium parasitizing the spur-thighed tortoise (Testudo graeca) in Tunisia. Parasite 26, 35.

Reviews, articles and short notes may be submitted. Fields include, but are not limited to: general, medical and veterinary parasitology; morphology, including ultrastructure; parasite systematics, including entomology, acarology, helminthology and protistology, and molecular analyses; molecular biology and biochemistry; immunology of parasitic diseases; host-parasite relationships; ecology and life history of parasites; epidemiology; therapeutics; new diagnostic tools.

All papers in Parasite are published in English. Manuscripts should have a broad interest and must not have been published or submitted elsewhere. No limit is imposed on the length of manuscripts.

Parasite (open-access) continues Parasite (print and online editions, 1994-2012) and Annales de Parasitologie Humaine et Comparée (1923-1993) and is the official journal of the Société Française de Parasitologie. 